\title{
Update on oncolytic viral therapy - targeting angiogenesis
}

This article was published in the following Dove Press journal:

OncoTargets and Therapy

30 July 2013

Number of times this article has been viewed

\author{
James R Tysome ${ }^{1-3}$ \\ Nick R Lemoine ${ }^{1,3}$ \\ Yaohe Wangl,3 \\ 'Centre for Molecular Oncology, \\ Barts Cancer Institute, Queen Mary \\ University of London, London, \\ United Kingdom; ${ }^{2}$ Department of \\ Otolaryngology, Cambridge University \\ Hospitals, Cambridge, United \\ Kingdom; ${ }^{3}$ Sino-British Research \\ Center for Molecular Oncology, \\ Zhengzhou University, Zhengzhou, \\ People's Republic of China
}

\begin{abstract}
Oncolytic viruses (OVs) have the ability to selectively replicate in and lyse cancer cells. Angiogenesis is an essential requirement for tumor growth. Like OVs, the therapeutic effect of many angiogenesis inhibitors has been limited, leading to the development of more effective approaches to combine antiangiogenic therapy with OVs. Angiogenesis can be targeted either directly by OV infection of vascular endothelial cells, or by arming OVs with antiangiogenic transgenes, which are subsequently expressed locally in the tumor microenvironment. In this review, we describe the development and targeting of OVs, the role of angiogenesis in cancer, and the progress made in arming viruses with antiangiogenic transgenes. Future developments required to optimize this approach are addressed.
\end{abstract}

Keywords: oncolytic virotherapy, cancer

\section{Introduction to oncolytic viral therapy}

Cancer remains a leading cause of death despite incremental advances in surgery, chemotherapy, and radiotherapy. This has led to the development of new treatment strategies. With increasing knowledge of the genetic defects and molecular basis of cancer, gene therapy has become an attractive option, although clinical trials to date have shown only moderate efficacy. Since cancer usually results from a combination of genetic defects, strategies to eradicate cancer cells themselves are likely to have a greater efficacy than attempts to correct each genetic defect individually. The ideal vector has tumor-selective oncolytic properties in that, as well as delivering gene therapy, it can selectively enter and destroy cancer cells, without affecting surrounding normal cells. It should also be safe to administer, have minimal side effects, be easy to mass-produce and purify, and be genetically stable in storage and use.

While nonviral vectors, including naked DNA or DNA packaged in liposomes and dendrimers, have been used in cancer gene therapy, ${ }^{1}$ it is viruses that have been recognized to be the most efficient means currently available for the delivery of therapeutic genes. The evolution of viruses over millions of years has resulted in their ability to evade our immune system, infect, and replicate efficiently in human cells before causing their death to facilitate viral spread. ${ }^{2}$ While the viral vectors developed initially were nonreplicating, it is the ability of viruses to replicate, so amplifying a small input dose to maximize therapeutic effect, that really sets them apart from other vectors. Interest has therefore shifted to the development of oncolytic viruses (OVs). These are replication-selective in that they have the ability to replicate in and cause death of tumor cells, while sparing normal cells. ${ }^{3}$ This property may be inherent or 
enhanced through genetic engineering and the viruses armed to deliver therapeutic transgenes, such as angiogenesis inhibitors.

The use of viruses for cancer treatment is not a new concept since, at the beginning of the 20th century, it was observed that a flu-like disease resulted in decreased tumor load in a patient with leukemia and that rabies vaccination was followed by regression of cervical cancer. ${ }^{4}$ OVs can be engineered to express foreign genes and, therefore, deliver gene therapy on a continuous basis to augment their therapeutic effect. This combination of mechanisms means that resistance, which often limits standard chemotherapy, is less likely to occur. ${ }^{5}$

\section{Barriers to oncolytic viruses}

Over the last two decades, thousands of OVs have been developed, resulting in many clinical trials but few examples of clinical efficacy. ${ }^{6}$ Replication-selective oncolytic adenovirus is the most well-researched, and d11520 (or H101 in the People's Republic of China) was approved as the world's first oncolytic virotherapy for the treatment of head and neck cancer. ${ }^{7}$ This has also been administered by intratumoral injection into patients with locally advanced pancreatic tumors in Phase I/II trials. ${ }^{8}$ Although treatments were well tolerated, efficacy was poor. The main barriers to oncolytic viral therapy have been recognized as viral attenuation caused by the genetic engineering to improve tumor selectivity, the effects of the tumor microenvironment, and the host immune response. ${ }^{9,10}$

\section{Tumor selectivity}

The first generation of OVs were inherently tumor selective in their replication and included Newcastle virus ${ }^{11}$ and reovirus. ${ }^{12,13}$ Second generation OVs were engineered to limit replication to tumors by inserting tumor-specific promoters, such as the prostate-specific antigen (PSA), upstream of the genes required for viral replication. ${ }^{14}$ The deletion of genes, such as thymidine kinase (TK), that are themselves required for viral replication in normal cells, but not in tumor cells also enhances tumor-selectivity. Many other strategies have been developed in order to increase the selectivity of OVs. ${ }^{10}$ However, the efficiency of cell lysis and cell-to-cell transfer of OVs alone in vivo is often poor since these modifications can result in the attenuation of antitumor potency.

\section{Tumor microenvironment}

The importance of the interaction between cancer cells and their environment is well recognized. ${ }^{15}$ Tumor development has many similarities with wound healing, as in tumor development, there is also a persistent inflammatory response, with many of the same cytokines released from the fibroblasts, which attract immune cells, including macrophages, which in turn, release further cytokines that promote angiogenesis. ${ }^{16}$ Considering these complex interactions, it is not surprising that OVs targeting the tumors alone have had limited efficacy.

Collagen in the extracellular matrix (ECM) has been found to be a physical barrier to the spread of OVs within tumors. It has been shown that inducing collagen degradation with a bacterial collagenase improved the spread and efficacy of an oncolytic herpes simplex virus. ${ }^{17}$ The construction of an oncolytic adenovirus expressing the collagenase matrix metalloproteinase (MMP)-9 also increased viral spread in human pancreatic and lung cancer models. ${ }^{18}$ The inevitable hypoxic environment in most tumors has also been found to attenuate oncolytic adenoviral therapy. ${ }^{19} \mathrm{OVs}$ can also increase the vascular permeability in tumors, stimulating angiogenesis. ${ }^{20}$ Antiangiogenic therapy may itself reduce the innate immune response by stabilizing the tumor vasculature and decreasing the immune cell infiltration of tumors. ${ }^{21}$

\section{Host immune response}

The host immune response to virus-infected tumors may be the most significant limitation to oncolytic viral therapy. Soon after virus delivery to tumors, an innate immune response is observed, with recruitment of neutrophils, natural killer cells, and macrophages. ${ }^{22}$ Inhibition of the innate immune response may enhance the efficacy of OVs. ${ }^{9}$ However, the step-wise deletion of virus virulence genes that normally cause evasion of the host immune response has been used to improve OV tumor selectivity. The host immune response is a double-edged sword for OV-based therapeutics. On the one hand, a vigorous host immune response to the OV can result in rapid viral clearance before the virus is able to exert a therapeutic effect or even result in tumor progression due to immunosuppression. The efficacy of multiple injections of the same virus may be further limited by a neutralizing antibody response. ${ }^{23}$ However, the host immune response may be critical to the efficacy of oncolytic viral therapy. This may be mediated via innate immune effectors, adaptive antiviral immune responses eliminating infected cells, or adaptive antitumor immune responses. ${ }^{24}$

\section{Choice of transgene expression by oncolytic viruses}

The choice of genes possible for cancer gene therapy is vast. The main mechanisms of action of potential therapeutic 
genes are those considered to be corrective, immunomodulatory, and cytoreductive, all of which have been delivered by OVs.

\section{Corrective genes}

Unregulated cell growth in cancers is caused by mutations in oncogenes or tumor suppressor genes (TSGs). Therefore, inhibiting oncogenes or upregulating TSGs may restore normal cell growth and division. The most commonly targeted TSG is p53, as mutations of this gene are estimated to be found in over half of all malignancies. ${ }^{25,26}$ In 2003, a recombinant, nonreplicating adenovirus expressing $p 53$ (rAd53 or Gendicine ${ }^{\mathrm{TM}}$; Schenzhen SiBiono Gene Tech Co, Ltd, Schenzhen, People's Republic of China) was approved by the State Food and Drug Administration of China for the treatment of head and neck squamous cell carcinoma and became the first licensed gene therapy product in the world. Another commonly mutated TSG is $p 16$, which has been delivered by oncolytic adenovirus to treat gastric cancer xenografts. ${ }^{27}$ However, since most cancers result from defects in several genes, this strategy has not been effective, and focus has moved to targeting signaling pathways.

\section{Immunomodulatory genes}

As discussed previously, the host's innate immune response to viruses can lead to their rapid clearance thus limiting transgene expression and antitumor efficacy. The adaptive immune response may preclude repeated virus administration through the formation of circulating antibodies. Many malignant cells express tumor-associated antigens (TAAs). Recognition of TAAs by antigen-presenting cells leads to the activation of TAA-specific CD8+ cytotoxic T lymphocytes (CTLs). These in turn, cause tumor cell death through direct lysis. Tumors avoid CTL destruction by limiting TAA presentation and reducing the expression of major histocompatibility complex class I (MHC I), which is also required for antigen recognition. ${ }^{28}$ Cancer gene therapy can enhance tumor cell recognition through increased TAA presentation or upregulated MHC I expression. ${ }^{29}$ Cytokine delivery by gene therapy, such as oncolytic adenovirus- or vaccinia virus (VV)-delivered interferon $\beta$, has shown potential in modulating the host immune response to improve tumor clearance. ${ }^{30,31}$ Granulocyte-macrophage colony-stimulating factor (GM-CSF)-armed OVs (herpes simplex virus [HSV] and VV) have shown encouraging results in clinical trials, ${ }^{32,33}$ although tumor-derived GM-CSF has also been recently demonstrated to drive the progression of cancer. ${ }^{34,35}$ The mechanism is thought to be similar in both situations, with GM-CSF suppressing T cell immunity, allowing OVs and tumor cells, respectively, to evade the host immune response.

\section{Cytoreductive genes}

Cytoreductive therapy targets cancer cells either directly or indirectly. Methods include gene-directed enzyme prodrug therapy (GDEPT) (also called suicide gene therapy) and antiangiogenic therapy. Acting in cancer cells only, GDEPT expresses a gene encoding an enzyme that converts a prodrug into a potential cytotoxin. The cytotoxin is produced exclusively within the target tumor to cause tumor cell death and regression. ${ }^{36}$ One example is an oncolytic adenovirus expressing a fusion protein that converts 5-fluorocytosine into the commonly used chemotherapeutic agent 5-fluorouracil. ${ }^{37}$ Virus-delivered GDEPT has entered Phase I clinical trials. ${ }^{38,39}$ The requirement of angiogenesis for the growth of all tumors has led to the discovery of a wide variety of angiogenesis inhibitors. This strategy will be now be explored in detail.

\section{Introduction to angiogenesis}

Angiogenesis is the growth of new capillary blood vessels from existing vessels. This is necessary for the growth of all tumors beyond 2 or $3 \mathrm{~mm}$ in diameter. ${ }^{40}$ Folkman proposed that the acquisition of an "angiogenic switch" was necessary for tumor growth and metastasis. ${ }^{41} \mathrm{He}$ first recognized this as an important factor in the development of other chronic diseases, such as atherosclerosis, chronic liver disease, and rheumatoid arthritis. This has led to the development of a huge range of antiangiogenic therapies, some of which are now in widespread clinical use, including small molecules and monoclonal antibody inhibitors. ${ }^{42,43}$ Viruses have been recognized as offering the possibility of targeted delivery of angiogenesis inhibitors, providing local expression of these proteins on a continual basis in order to maximize efficacy and limit side effects. This review will focus on the angiogenesis inhibitors delivered by replicating OVs for cancer therapy, forming an update from our previous review on this topic. ${ }^{44}$

\section{Specific importance of angiogenesis in cancer}

Angiogenesis is regulated by the balance of angiogenic growth factors and inhibitors, which are released from endothelial cells (ECs), monocytes, platelets, and smooth muscle and tumor cells. ${ }^{45}$ The normal physiological situation in solid organ vasculature is an excess of inhibitors. When an excess of growth factors is present, as is frequently the case in tumors, the balance is tipped in favor of angiogenesis. 
Vascular endothelial growth factor (VEGF) and other growth factors released from tumors bind to receptors on both the endothelial cells of nearby blood vessels and circulating bone marrow-derived epithelial progenitor cells, resulting in their activation, proliferation, and production of enzymes. ${ }^{46}$ The resulting enzymes dissolve holes in the basement membrane of the surrounding blood vessels, allowing proliferating ECs to migrate out toward the tumor. MMPs produced by ECs dissolve the surrounding stroma, allowing the ECs to advance toward the tumor, using integrins including $\alpha v \beta 3$ and $\alpha v \beta 6$ to direct them. ${ }^{47}$ The ECs then remodel and form tubes, which connect into loops through the tumor mass, so forming complete blood vessels. Structural support cells, such as smooth muscle cells, then follow, although tumor blood vessels remain leaky and have a poorly formed basement membrane, two factors that have been proposed to aid the inherent tumor specificity of some viral vectors.

The development of angiogenesis inhibitors has become a broad and active area of cancer research..$^{45,48-51} \mathrm{~A}$ wide range of angiogenesis inhibitors have been discovered and the most widely studied include protease inhibitors, tyrosine kinase inhibitors, chemokines, interleukins (ILs) (eg, IL-8, IL-12, IL-18), and proteolytic fragments of diverse molecules (eg, endostatin, angiostatin, vaculostatin, canstatin). These antiangiogenic molecules function in multiple ways, including inhibiting endothelial cell proliferation, migration, protease activity and tubule formation, as well as inducing apoptosis.

Antiangiogenic agents offer lower toxicity than most con-

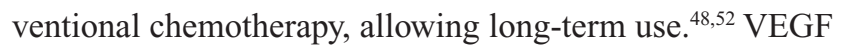
is the most commonly targeted angiogenic growth factor, and the first angiogenesis inhibitor to be licensed in Europe was bevacizumab. This class I inhibitor is an antibody that specifically blocks VEGF and was licensed in January 2005 for the treatment of metastatic colorectal carcinoma, following its success in clinical trials. ${ }^{53}$ However, resistance has been seen in patients with other tumor types, where multiple angiogenic factors may be produced by primary tumors. ${ }^{54}$

Despite great promise, the results obtained with the use of these peptide inhibitors alone in clinical trials have been disappointing, and regimes combining angiogenesis inhibitors with standard chemotherapeutic regimes are often required. ${ }^{42,43}$ Many angiogenesis inhibitors are not directly cytotoxic to tumor cells, but need to be expressed on a continuous basis to inhibit ECs effectively. Initial efforts focused on the targeting of VEGF- and tumor-derived VEGF-signaling. However, resistance was observed, and a greater understanding of the mechanisms of drug resistance ${ }^{50}$ and the concept that sustained local delivery of angiogenesis inhibitors to tumors may be more effective has led to the development of antiangiogenic cancer gene therapy. ${ }^{45}$

\section{Targeting endothelial cells with oncolytic viruses}

Some OVs display an innate ability to infect ECs in tumors, while sparing those in normal vessels. ${ }^{55}$ Intravenous delivery of a vesicular stomatitis virus in a murine colorectal carcinoma xenograft model showed direct infection of ECs. This induced neutrophil infiltration, leading to microclot formation with tumor-associated vasculature, resulting in a large bystander effect of cell death within the tumor. ${ }^{56} \mathrm{An} \mathrm{HSV}$ delivered intravenously in a murine ovarian carcinoma model has also been found to specifically infect tumor-associated ECs, causing cell death while sparing the ECs in normal organs. ${ }^{57}$ In a Phase I clinical trial, intravenous delivery of oncolytic VV engineered to target cells with activation of the Ras/mitogen-activated protein kinase (MAPK) pathway was found to selectively infect tumor-associated ECs, sparing normal ECs. ${ }^{58}$ This provides a useful platform for the further development of OVs armed with therapeutic transgenes in the future.

\section{Arming oncolytic viruses with angiogenesis inhibitors}

While nanoparticles, liposomes, and naked plasmid DNA electroporation have all been used to deliver antiangiogenesis gene therapy, it is viruses that are the most promising vectors for the delivery of angiogenesis inhibitors. ${ }^{59}$ The ability of OVs to infect and selectively amplify the input dose of virus in the target tumor has been exploited to address some of the limitations of nonreplicating viruses. ${ }^{23,60}$ OVs can selectively target and kill tumor ECs as well as tumor cells, although there is evidence that they can themselves increase vascular permeability in tumors, stimulating angiogenesis. ${ }^{20}$ The combination of antiangiogenic therapy delivered by an OV may prevent this through reduction of the host immune response, by stabilizing tumor vasculature and decreasing immune cell infiltration. ${ }^{21}$ The selective expression of angiogenesis inhibitors in the tumor microenvironment prevents further tumor growth, allowing the viral progeny produced through replication to spread through tumors, infecting and inducing lysis of cancer cells in order to achieve tumor clearance.

Since our last review on this subject was published ${ }^{44}$ there have been 17 new OVs armed with antiangiogenic genes reported in animal models, making a total of 32 studies in 
the literature (Tables $1-3$ ). There are still no clinical trials reported nor registered to date.

\section{Targeting VEGF}

VEGF has a key role in the signaling pathways that mediate angiogenesis, tumor growth, and metastasis. Monoclonal antibodies against VEGF are now in widespread clinical use in oncology. Since VEGF is highly expressed in many cancers, this pathway has been targeted by many OVs expressing angiogenesis inhibitors. The first reported OV expressing an angiogenesis inhibitor was a first-generation oncolytic adenovirus (ONYX-015, E1B55k, and E3B-deleted adenovirus) armed with a soluble VEGF-receptor inhibitor, sFlt-1, which was effective in an animal model of human colorectal cancer. ${ }^{62}$ The combination of a second-generation oncolytic adenovirus (d1922/47, with E1ACR2 mutation and E3B deletion) and a nonreplicating adenovirus expressing Flk1-Fc, a soluble ectodomain of the VEGF receptor, was more effective than either virus alone. ${ }^{63}$ Another E1B55 kDa-deleted oncolytic adenovirus was effective in a human colorectal model by expressing vascular endothelial growth inhibitor (VEGI). ${ }^{64}$ Ad- $\Delta 7 \mathrm{~B}-\mathrm{KOX}$ (E1B19 kDa and E1B55 kDa gene-deleted), an oncolytic adenovirus expressing a VEGF promoter targeted artificial zinc-finger protein inserted into the $E 3$ gene, reduced VEGF expression, and increased the survival of animals bearing human glioblastoma xenografts. ${ }^{65}$

More recently, a group has published results of both oncolytic adenovirus ${ }^{66}$ (Ad5/3 serotype with hypoxia inducible factor [HIF]-promoter) and $\mathrm{VV}^{67}$ (TK- and vaccinia growth factor-deleted) expressing VEGF-1-immunoglobulin (Ig), a soluble inhibitor that binds VEGF without inducing vascular EC mitogenesis. ${ }^{68} \mathrm{VV}$ has also been used to deliver a single chain antibody to VEGF, which was effective in a canine xenograft model. ${ }^{69}$ Targeting the VEGF pathway has been effective in animal models and shows promise for translation to clinical studies in the future.

\section{Targeting interleukins and chemokines}

IL-24 is a good candidate for expression by OVs, as it is an effective antiangiogenic cytokine and as well, induces apoptosis and reduced growth in many tumors. ${ }^{70,71}$ Three different oncolytic adenoviruses have been engineered to express IL-24, ${ }^{72-74}$ with coexpression of arrestin, and these were effective in a melanoma model. ${ }^{74}$ IL- 8 has been targeted, as it promotes angiogenesis, tumor growth, and metastasis. ${ }^{75} \mathrm{An}$ oncolytic adenovirus delivering small interfering ribonucleic acid (siRNA) against IL-8 was effective in a range of human xenograft models, including metastatic breast cancer. ${ }^{76}$ IL-18 has also been identified as an angiogenic inhibitor and tumor suppressor. ${ }^{77}$ An oncolytic E1b55 kDa-deleted adenovirus expressing IL-18 was effective in a human renal carcinoma xenograft model. IL-12 ${ }^{78}$ and chemokine platelet factor 4 $(\mathrm{PF} 4)^{79}$ are also potent antiangiogenic agents, and oncolytic HSVs armed with IL-12 or PF4 have shown promise in animal models. ${ }^{80-82}$

\section{Targeting matrix metalloproteinases}

MMPs play a pivotal role in angiogenesis by degrading the stroma of the ECM that surrounds blood vessels, leading to EC proliferation, migration, and new capillary formation. ${ }^{83}$ Tissue inhibitors of metalloproteinases (TIMP) have been developed for antiangiogenic therapy. The only reported virus expressing a TIMP is Ad 24 TIMP-3, an oncolytic adenovirus expressing TIMP-3. However, despite reducing levels of MMP-2, this did not lead to decreased tumor growth or improved survival in a human glioma model. ${ }^{84}$

Table I Oncolytic viruses expressing inhibitors of the VEGF pathway

\begin{tabular}{|c|c|c|}
\hline Oncolytic virus and angiogenesis inhibitor expressed & Tumor model & Reference \\
\hline ZD55-VEGI-25I, oncolytic adenovirus (EIB55 KDa deleted) expressing VEGI & Human cervical and colorectal xenografts & $\mathrm{Xiao}^{64}$ \\
\hline $\begin{array}{l}\text { vvdd-VEGFR-I-Ig, oncolytic vaccinia virus (thymidine kinase and vaccinia virus } \\
\text { growth factor deleted) expressing VEGFR-I-Ig fusion protein }\end{array}$ & Murine renal cancer & Guse $^{67}$ \\
\hline $\begin{array}{l}\text { Ad5/3-9HIF-Delta24-VEGFR-I-Ig, oncolytic adenovirus (5/3-serotype chimera) } \\
\text { expressing VEGFR-I-Ig fusion protein }\end{array}$ & Murine renal cancer & Guse $^{66}$ \\
\hline $\begin{array}{l}\text { Oncolytic adenovirus d } 1922 / 47 \text { (EIA CR2 region mutated) + nonreplicative } \\
\text { adenoviral vector expressing FIkI-Fc }\end{array}$ & Human colon and prostate cancer & Thorne $^{63}$ \\
\hline $\begin{array}{l}\text { Ad- } \triangle \mathrm{B} 7-\mathrm{KOX} \text {, oncolytic adenovirus (EIBI9 kDa and EIB55 kDa gene-deleted) } \\
\text { expressing VEGF promoter-targeted transcriptional repressor ZFP }\end{array}$ & Human glioblastoma & Kang ${ }^{65}$ \\
\hline $\begin{array}{l}\text { ZDD-sflt-I, oncolytic adenovirus (EIB55 KDa deleted) expressing sflt-I } \\
\text { (the first three extracellular domains of FLTI, the VEGF receptor-I) }\end{array}$ & Human colon cancer & Zhang ${ }^{62}$ \\
\hline GLV-IhI09, oncolytic vaccinia virus expressing a single-chain antibody to VEGF & Canine sarcoma and prostate cancer & Patil $^{69}$ \\
\hline
\end{tabular}

Abbreviations: Ig, immunoglobulin; VEGF, vascular endothelial growth factor; VEGFR, vascular endothelial growth factor receptor; VEGI, vascular endothelial growth inhibitor; vv, vaccinia virus; ZFP, zinc finger protein. 
Table 2 Oncolytic viruses expressing cytokines and chemokines

\begin{tabular}{|c|c|c|c|}
\hline $\begin{array}{l}\text { Cytokines and } \\
\text { chemokines }\end{array}$ & Oncolytic viruses and genetic modification & Tumor model & References \\
\hline Interleukin-18 & ZD55-IL-18, oncolytic adenovirus (EIB55 KDa deleted) expressing IL- I8 & Human renal cancer xenografts & Zheng ${ }^{106}$ \\
\hline Interleukin-24 & $\begin{array}{l}\text { Ad.DD3-EIA-IL-24, oncolytic adenovirus (DD3 replaces EIA promoter) } \\
\text { expressing IL-24 }\end{array}$ & Human prostate cancer & Fan 101 \\
\hline Interleukin-24 & $\begin{array}{l}\text { Ad.sp.EIA }((\Delta 24)) \cdot \operatorname{EIB}((\Delta 55)) \cdot \mathrm{IL}-24 \text {, oncolytic adenovirus (EIA } 24 \mathrm{kDa} \\
\text { and EIB } 55 \mathrm{kDa} \text { deleted) expressing IL-24 under the surviving promoter }\end{array}$ & Human lung xenografts & $\mathrm{Xiao}^{73}$ \\
\hline Interleukin-24 & Conditionally replicating adenovirus expressing IL-24 and arrestin & Human melanoma & $\mathrm{Chai}^{74}$ \\
\hline Interleukin-8 & $\begin{array}{l}\text { Ad- } \Delta \text { B7-U6shIL8, oncolytic adenovirus (EIB55 KDa deleted) } \\
\text { expressing IL-8-specific shRNA }\end{array}$ & Human solid tumors & Yoo ${ }^{76}$ \\
\hline Interleukin-12 & NVI042, oncolytic HSV (NV 1023) expressing murine IL-I2 & $\begin{array}{l}\text { Murine prostate, head } \\
\text { and neck cancer }\end{array}$ & $\begin{array}{l}\text { Varghese, } \\
\text { Wong }\end{array}$ \\
\hline Platelet factor 4 & bG47Delta-PF4, oncolytic HSV expressing PF4 & Human and mouse glioma & $\operatorname{Liu}^{104}$ \\
\hline $\begin{array}{l}\text { Tissue inhibitor of } \\
\text { metalloproteinase-3 }\end{array}$ & $\begin{array}{l}\text { Ad } \Delta 24 \text { TIM-3, oncolytic adenovirus (EIA CR2 region-mutated, } \\
\text { aka, } \Delta 24 \text { or d1922/47) expressing TIMP3 gene }\end{array}$ & Human glioma & Lamfers $^{84}$ \\
\hline
\end{tabular}

Abbreviations: HSV, herpes simplex virus; IL, interleukin; PF4, platelet factor 4; shRNA, short hairpin ribonucleic acid; TIMP3, tissue inhibitor of metalloproteinase-3.

Table 3 Oncolytic viruses expressing other endogenous inhibitors

\begin{tabular}{|c|c|c|c|}
\hline Endogenous inhibitor & Oncolytic viruses and genetic modification & Tumor model & Reference \\
\hline \multirow[t]{12}{*}{ Endostatin/angiostatin } & $\begin{array}{l}\text { VhEA, oncolytic Lister strain vaccinia virus expressing human } \\
\text { endostatin-angiostatin fusion protein }\end{array}$ & $\begin{array}{l}\text { Human head and neck } \\
\text { cancer }\end{array}$ & Tysome 99 \\
\hline & $\begin{array}{l}\text { Ad-hE, oncolytic adenovirus expressing human endostatin } \\
\text { encapsulated in PEG-PE cationic liposome }\end{array}$ & Human ovarian cancer & Yang ${ }^{93}$ \\
\hline & $\begin{array}{l}\mathrm{G} 47 \Delta \text {-mAngio, oncolytic herpes simplex virus expressing murine } \\
\text { angiostatin in combination with bevacizumab }\end{array}$ & Human glioma & Zhang $^{94}$ \\
\hline & $\begin{array}{l}\text { rAAV-TIE, oncolytic adeno-associated virus expressing endostatin } \\
\text { and HSV-thymidine kinase }\end{array}$ & Human bladder cancer & $\operatorname{Pan}^{91}$ \\
\hline & $\begin{array}{l}\text { VVhEA, oncolytic Lister strain vaccinia virus arming with human } \\
\text { endostatin-angiostatin fusion protein gene }\end{array}$ & Human pancreatic cancer & Tysome $^{98}$ \\
\hline & $\begin{array}{l}\text { EndoAngio-PRRA, a prostate-restricted, replication-competent } \\
\text { adenovirus expressing endostatin-angiostatin fusion gene }\end{array}$ & Human prostate cancer & $\mathrm{Li}^{96}$ \\
\hline & $\begin{array}{l}\text { HSV-Endo, oncolytic HSV-I mutant expressing murine } \\
\text { endostatin gene }\end{array}$ & Human colon cancer & Mullen ${ }^{88}$ \\
\hline & $\begin{array}{l}\text { AE6 I8, an oncolytic HSV-I G027 expressing } \\
\text { endostatin-angiostatin fusion protein }\end{array}$ & Human lung cancer & Yang ${ }^{23}$ \\
\hline & $\begin{array}{l}\text { CNHK200-mE, oncolytic adenovirus (EIB55 KDa deleted) } \\
\text { expressing mouse endostatin }\end{array}$ & $\begin{array}{l}\text { Human hepatocellular } \\
\text { carcinoma }\end{array}$ & $\mathrm{Li}^{86}$ \\
\hline & $\begin{array}{l}\text { CNHK300-mE, oncolytic adenovirus (hTERT-promoter to drive } \\
\text { the expression of the adenovirus EIA gene) expressing mouse } \\
\text { endostatin }\end{array}$ & $\begin{array}{l}\text { Human hepatocellular } \\
\text { carcinoma and gastric } \\
\text { cancer }\end{array}$ & $\mathrm{Li}^{87}$ Zhang $^{90}$ \\
\hline & $\begin{array}{l}\text { CNHK500-mE, oncolytic adenovirus (Ela and Elb genes } \\
\text { controlled by the human telomerase reverse transcriptase } \\
\text { promoter and the hypoxia response element) expressing } \\
\text { mouse endostatin }\end{array}$ & $\begin{array}{l}\text { Human nasopharyngeal } \\
\text { cancer }\end{array}$ & $\mathrm{Su}^{89}$ \\
\hline & HSV-Endo, oncolytic herpes simplex virus-I expressing endostatin & Murine lung cancer & Goodwin ${ }^{92}$ \\
\hline Vaculostatin & $\begin{array}{l}\text { RAMBO expressing vaculostatin (Vstat } 120) \text { under control } \\
\text { of the HSV IE } 4 / 5 \text { promoter }\end{array}$ & Human glioma & Hardcastle ${ }^{103}$ \\
\hline Plasminogen kringle 5 & $\begin{array}{l}\text { ZD55-mK5, oncolytic adenovirus (EIB55 KDa deleted) } \\
\text { expressing mutated kringle } 5 \text { of human plasminogen) }\end{array}$ & Human colon cancer & Fan $^{101}$ \\
\hline Canstastin & Oncolytic adenovirus (EIB55 KDa deleted) expressing canstatin & Human pancreatic cancer & $\mathrm{He}^{102}$ \\
\hline $\begin{array}{l}\text { Fibroblast growth } \\
\text { factor receptor }\end{array}$ & $\begin{array}{l}\text { bG47Delta-dnFGFR, oncolytic herpes simplex virus arming } \\
\text { with a dominant-negative FGF receptor }\end{array}$ & $\begin{array}{l}\text { Human glioma and mouse } \\
\text { malignant peripheral nerve } \\
\text { sheath tumor }\end{array}$ & $\operatorname{Liu}^{104}$ \\
\hline
\end{tabular}

Abbreviations: FGF, fibroblast growth factor; hTERT, human telomerase reverse transcriptase; HSV, herpes simplex virus; PEG-PE, phospholipid derivative of polyethylene glycol; RAMBO, rapid antiangiogenesis mediated by oncolytic virus. 


\section{Other endogenous inhibitors}

Endostatin has displayed the broadest anticancer spectrum of all endogenous inhibitors currently identified and inhibits migration of tumor cells and ECs as well as invasion of tumor cells. ${ }^{85}$ The endostatin gene has been engineered to be expressed by oncolytic adenovirus, adeno-associated virus and $\mathrm{HSV}^{86-93}$ showing better efficacy than control or nonreplicating viruses expressing endostatin.

Angiostatin, a $38 \mathrm{kDa}$ fragment of plasminogen, inhibits EC proliferation and migration as well as inducing apoptosis. The strategy of combining angiogenesis inhibitors that work through different pathways has been investigated since they tend to exhibit a low side-effect profile when compared with conventional chemotherapy. An oncolytic adenovirus expressing angiostatin has shown promise when delivered locally following systemic bevacizumab. ${ }^{94}$ Endostatin and angiostatin have been found to act synergistically when used in combination, which led to the development of an endostatin-angiostatin fusion gene. ${ }^{95}$ This fusion gene has been incorporated into oncolytic HSV, adenovirus, and VV. ${ }^{96-98}$ We found that oncolytic VV expressing the fusion protein displayed superior efficacy over ONYX-015 in a head and neck cancer model..$^{99}$

Another fragment of plasminogen, kringle 5, inhibits EC proliferation more effectively than angiostatin. ${ }^{100}$ Kringle 5 and a mutant kringle 5 ( $\mathrm{mK} 5$, with leucine 71 changed to arginine) have been delivered by a first-generation oncolytic adenovirus (ONYX-015, E1B55 kDa-deleted). ${ }^{101}$ The ZD55-mK5 virus significantly suppressed tumor growth and improved survival in a human colorectal xenograft model. ONYX-015 has also been used to express canstatin, a $24 \mathrm{kDa}$ fragment of type IV collagen. ${ }^{102}$ An oncolytic HSV expressing vasculostatin, a fragment of brain-specific angiogenesis inhibitor-1, has shown promise in a human pancreatic model. ${ }^{103}$

Fibroblast growth factor (FGF) signaling is another important mediator of both $\mathrm{EC}$ and tumor cell migration essential in angiogenesis. A novel oncolytic HSV armed with a dominant-negative FGF receptor has been developed and has been shown to be more effective than its unarmed counterpart at inhibiting tumor growth and angiogenesis, in both human and mouse tumor models in vivo. ${ }^{104}$

\section{Future developments}

Many different angiogenesis inhibitors have been used to arm OVs. Most have shown promise in animal models, but none have reached clinical trials. The major barriers limiting the efficacy of OVs are still tumor selectivity, the effect on the tumor microenvironment, and the host immune response to virus-infected tumor cells. ${ }^{9}$ Many strategies are being developed to overcome these obstacles and to optimize OV delivery. Lessons should be learnt from standard chemotherapeutic regimes, which often combine multiple agents with different mechanisms of action. The same approach should be used with angiogenesis inhibitors, where less toxicity is usually observed when compared with most standard chemotherapy drugs.

Many antiangiogenic drugs have the ability to constrict abnormal leaky tumor vessels. ${ }^{105}$ This ability to temporarily normalize tumor vasculature provides a therapeutic window during which systemic delivery of OVs may be improved. Clinical studies should concentrate on combining OVs with standard treatment regimes in order to enhance their efficacy.

\section{Disclosure}

The authors report no conflicts of interest in this work.

\section{References}

1. Kaneda Y, Tabata Y. Non-viral vectors for cancer therapy. Cancer Sci. 2006;97(5):348-354.

2. Young LS, Searle PF, Onion D, Mautner V. Viral gene therapy strategies: from basic science to clinical application. J Pathol. 2006;208(2): 299-318.

3. Hawkins LK, Lemoine NR, Kirn D. Oncolytic biotherapy: a novel therapeutic plafform. Lancet Oncol. 2002;3(1):17-26.

4. Kelly E, Russell SJ. History of oncolytic viruses: genesis to genetic engineering. Mol Ther. 2007;15(4):651-659.

5. Kirn D, Martuza RL, Zwiebel J. Replication-selective virotherapy for cancer: biological principles, risk management and future directions Nat Med. 2001;7(7):781-787.

6. Liu TC, Galanis E, Kirn D. Clinical trial results with oncolytic virotherapy: a century of promise, a decade of progress. Nat Clin Pract Oncol. 2007;4(2):101-117.

7. Garber K. China approves world's first oncolytic virus therapy for cancer treatment. J Natl Cancer Inst. 2006;98(5):298-300.

8. Hecht JR, Bedford R, Abbruzzese JL, et al. A phase I/II trial of intratumoral endoscopic ultrasound injection of ONYX-015 with intravenous gemcitabine in unresectable pancreatic carcinoma. Clin Cancer Res. 2003;9(2):555-561.

9. Liu TC, Kirn D. Gene therapy progress and prospects cancer: oncolytic viruses. Gene Ther. 2008;15(12):877-884.

10. Wong HH, Lemoine NR, Wang Y. Oncolytic viruses for cancer therapy: overcoming the obstacles. Viruses. 2010;2(1):78-106.

11. Sinkovics JG, Horvath JC. Newcastle disease virus (NDV): brief history of its oncolytic strains. J Clin Virol. 2000;16(1):1-15.

12. Comins C, Heinemann L, Harrington K, Melcher A, De Bono J, Pandha H. Reovirus: viral therapy for cancer 'as nature intended'. Clin Oncol (R Coll Radiol). 2008;20(7):548-554.

13. Thorne SH, Hwang TH, O'Gorman WE, et al. Rational strain selection and engineering creates a broad-spectrum, systemically effective oncolytic poxvirus, JX-963. J Clin Invest. 2007;117(11):3350-3358.

14. Li X, Zhang YP, Kim HS, et al. Gene therapy for prostate cancer by controlling adenovirus E1 a and E4 gene expression with PSES enhancer. Cancer Res. 2005;65(5):1941-1951. 
15. Bissell MJ, Radisky D. Putting tumours in context. Nat Rev Cancer. 2001;1(1):46-54.

16. Dvorak HF. Tumors: wounds that do not heal. Similarities between tumor stroma generation and wound healing. N Engl J Med. 1986; 315(26):1650-1659.

17. McKee TD, Grandi P, Mok W, et al. Degradation of fibrillar collagen in a human melanoma xenograft improves the efficacy of an oncolytic herpes simplex virus vector. Cancer Res. 2006;66(5):2509-2513.

18. Cheng J, Sauthoff H, Huang Y, et al. Human matrix metalloproteinase8 gene delivery increases the oncolytic activity of a replicating adenovirus. Mol Ther. 2007;15(11):1982-1990.

19. Pipiya T, Sauthoff H, Huang YQ, et al. Hypoxia reduces adenoviral replication in cancer cells by downregulation of viral protein expression. Gene Ther. 2005;12(11):911-917.

20. Aghi M, Rabkin SD, Martuza RL. Angiogenic response caused by oncolytic herpes simplex virus-induced reduced thrombospondin expression can be prevented by specific viral mutations or by administering a thrombospondin-derived peptide. Cancer Res. 2007;67(2):440-444.

21. Kurozumi K, Hardcastle J, Thakur R, et al. Effect of tumor microenvironment modulation on the efficacy of oncolytic virus therapy. J Natl Cancer Inst. 2007;99(23):1768-1781.

22. Chiocca EA. The host response to cancer virotherapy. Curr Opin Mol Ther. 2008;10(1):38-45.

23. Parato KA, Senger D, Forsyth PA, Bell JC. Recent progress in the battle between oncolytic viruses and tumours. Nat Rev Cancer. 2005;5(12):965-976.

24. Prestwich RJ, Harrington KJ, Pandha HS, Vile RG, Melcher AA, Errington F. Oncolytic viruses: a novel form of immunotherapy. Expert Rev Anticancer Ther. Oct 2008;8(10):1581-1588.

25. Shiraishi K, Kato S, Han SY, et al. Isolation of temperature-sensitive p53 mutations from a comprehensive missense mutation library. J Biol Chem. Jan 2 2004;279(1):348-355.

26. Peng Z. Current status of gendicine in China: recombinant human Ad-p53 agent for treatment of cancers. Hum Gene Ther. Sep 2005;16(9):1016-1027.

27. Ma J, He X, Wang W, et al. E2F promoter-regulated oncolytic adenovirus with p16 gene induces cell apoptosis and exerts antitumor effect on gastric cancer. Dig Dis Sci. 2009;54(7):1425-1431.

28. Ochsenbein AF. Principles of tumor immunosurveillance and implications for immunotherapy. Cancer Gene Ther. 2002;9(12):1043-1055.

29. Vile RG, Russell SJ, Lemoine NR. Cancer gene therapy: hard lessons and new courses. Gene Ther. 2000;7(1):2-8.

30. Sterman DH, Recio A, Carroll RG, et al. A phase I clinical trial of single-dose intrapleural IFN-beta gene transfer for malignant pleural mesothelioma and metastatic pleural effusions: high rate of antitumor immune responses. Clin Cancer Res. 2007;13(15 Pt 1): 4456-4466.

31. Kirn DH, Wang Y, Le Boeuf F, Bell J, Thorne SH. Targeting of interferonbeta to produce a specific, multi-mechanistic oncolytic vaccinia virus. PLoS Med. 2007;4(12):e353.

32. Heo J, Reid T, Ruo L, et al. Randomized dose-finding clinical trial of oncolytic immunotherapeutic vaccinia JX-594 in liver cancer. Nat Med. 2013;19(3):329-336.

33. Breitbach CJ, Burke J, Jonker D, et al. Intravenous delivery of a multimechanistic cancer-targeted oncolytic poxvirus in humans. Nature. 2011;477(7362):99-102.

34. Pylayeva-Gupta Y, Lee KE, Hajdu CH, Miller G, Bar-Sagi D. Oncogenic Kras-induced GM-CSF production promotes the development of pancreatic neoplasia. Cancer Cell. 2012;21(6):836-847.

35. Bayne LJ, Beatty GL, Jhala N, et al. Tumor-derived granulocytemacrophage colony-stimulating factor regulates myeloid inflammation and $\mathrm{T}$ cell immunity in pancreatic cancer. Cancer Cell. 2012;21(6):822-835.

36. Greco O, Dachs GU. Gene directed enzyme/prodrug therapy of cancer: historical appraisal and future prospectives. J Cell Physiol. 2001; 187(1):22-36.
37. Dias JD, Liikanen I, Guse K, et al. Targeted chemotherapy for head and neck cancer with a chimeric oncolytic adenovirus coding for bifunctional suicide protein FCU1. Clin Cancer Res. 2010;16(9): 2540-2549.

38. Braybrooke JP, Slade A, Deplanque G, et al. Phase I study of MetXiaP450 gene therapy and oral cyclophosphamide for patients with advanced breast cancer or melanoma. Clin Cancer Res. 2005;11(4): $1512-1520$.

39. Palmer DH, Mautner V, Mirza D, et al. Virus-directed enzyme prodrug therapy: intratumoral administration of a replication-deficient adenovirus encoding nitroreductase to patients with resectable liver cancer. J Clin Oncol. 2004;22(9):1546-1552.

40. Folkman J. Tumor angiogenesis: therapeutic implications. $N$ Engl $J$ Med. 1971;285(21):1182-1186.

41. Folkman J. Role of angiogenesis in tumor growth and metastasis. Semin Oncol. 2002;29(6 Suppl 16):15-18.

42. Laskin J, Crinò L, Felip E, et al. Safety and efficacy of first-line bevacizumab plus chemotherapy in elderly patients with advanced or recurrent nonsquamous non-small cell lung cancer: safety of avastin in lung trial (MO19390). J Thorac Oncol. 2012;7(1):203-211.

43. Sobrero A, Ackland S, Clarke S, et al. Phase IV study of bevacizumab in combination with infusional fluorouracil, leucovorin and irinotecan (FOLFIRI) in first-line metastatic colorectal cancer. Oncology. 2009;77(2):113-119.

44. Tysome JR, Lemoine NR, Wang Y. Combination of anti-angiogenic therapy and virotherapy: arming oncolytic viruses with anti-angiogenic genes. Curr Opin Mol Ther. 2009;11(6):664-669.

45. Tandle A, Blazer DG III, Libutti SK. Antiangiogenic gene therapy of cancer: recent developments. J Transl Med. 2004;2(1):22.

46. Dome B, Dobos J, Tovari J, et al. Circulating bone marrow-derived endothelial progenitor cells: characterization, mobilization, and therapeutic considerations in malignant disease. Cytometry A. 2008;73(3): 186-193.

47. Pandya NM, Dhalla NS, Santani DD. Angiogenesis - a new target for future therapy. Vascul Pharmacol. 2006;44(5):265-274.

48. Ma J, Waxman DJ. Combination of antiangiogenesis with chemotherapy for more effective cancer treatment. Mol Cancer Ther. 2008;7(12): 3670-3684.

49. Sessa C, Guibal A, Del Conte G, Rüegg C. Biomarkers of angiogenesis for the development of antiangiogenic therapies in oncology: tools or decorations? Nat Clin Pract Oncol. 2008;5(7):378-391.

50. Bottsford-Miller JN, Coleman RL, Sood AK. Resistance and escape from antiangiogenesis therapy: clinical implications and future strategies. J Clin Oncol. 2012;30(32):4026-4034.

51. Albini A, Tosetti F, Li VW, Noonan DM, Li WW. Cancer prevention by targeting angiogenesis. Nat Rev Clin Oncol. 2012;9(9): 498-509.

52. Boehm T, Folkman J, Browder T, O’Reilly MS. Antiangiogenic therapy of experimental cancer does not induce acquired drug resistance. Nature. 1997;390(6658):404-407.

53. Hurwitz H, Fehrenbacher L, Novotny W, et al. Bevacizumab plus irinotecan, fluorouracil, and leucovorin for metastatic colorectal cancer. N Engl J Med. 2004;350(23):2335-2342.

54. Relf M, LeJeune S, Scott PA, et al. Expression of the angiogenic factors vascular endothelial cell growth factor, acidic and basic fibroblast growth factor, tumor growth factor beta-1, platelet-derived endothelial cell growth factor, placenta growth factor, and pleiotrophin in human primary breast cancer and its relation to angiogenesis. Cancer Res. 1997;57(5):963-969.

55. Angarita FA, Acuna SA, Ottolino-Perry K, Zerhouni S, McCart JA. Mounting a strategic offense: fighting tumor vasculature with oncolytic viruses. Trends Mol Med. 2013;19(6):378-392.

56. Breitbach CJ, De Silva NS, Falls TJ, et al. Targeting tumor vasculature with an oncolytic virus. Mol Ther. 2011;19(5):886-894.

57. Benencia F, Courreges MC, Conejo-Garcia JR, et al. Oncolytic HSV exerts direct antiangiogenic activity in ovarian carcinoma. Hum Gene Ther. 2005;16(6):765-778 
58. Breitbach CJ, Arulanandam R, De Silva N, et al. Oncolytic vaccinia virus disrupts tumor-associated vasculature in humans. Cancer Res. 2013;73(4):1265-1275.

59. Lau K, Bicknell R. Antiangiogenic gene therapy. Gene Ther. 1999;6(11): 1793-1795.

60. Kirn DH, Thorne SH. Targeted and armed oncolytic poxviruses: a novel multi-mechanistic therapeutic class for cancer. Nat Rev Cancer. 2009;9(1):64-71.

61. ClinicalTrials.gov. United States National Institute of Health; 2013. http://www.clinicaltrials.gov/. Accessed March 3, 2013.

62. Zhang Z, Zou W, Wang J, et al. Suppression of tumor growth by oncolytic adenovirus-mediated delivery of an antiangiogenic gene, soluble Flt-1. Mol Ther. 2005;11(4):553-562.

63. Thorne SH, Tam BY, Kirn DH, Contag CH, Kuo CJ. Selective intratumoral amplification of an antiangiogenic vector by an oncolytic virus produces enhanced antivascular and anti-tumor efficacy. Mol Ther. 2006;13(5):938-946.

64. Xiao T, Fan JK, Huang HL, Gu JF, Li LY, Liu XY. VEGI-armed oncolytic adenovirus inhibits tumor neovascularization and directly induces mitochondria-mediated cancer cell apoptosis. Cell Res. 2010;20(3): 367-378.

65. Kang YA, Shin HC, Yoo JY, Kim JH, Kim JS, Yun CO. Novel cancer antiangiotherapy using the VEGF promoter-targeted artificial zinc-finger protein and oncolytic adenovirus. Mol Ther. 2008;16(6):1033-1040.

66. Guse K, Diaconu I, Rajecki M, et al. Ad5/3-9HIF-Delta24-VEGFR$1-\mathrm{Ig}$, an infectivity enhanced, dual-targeted and antiangiogenic oncolytic adenovirus for kidney cancer treatment. Gene Ther. 2009;16(8): 1009-1020.

67. Guse K, Sloniecka M, Diaconu I, et al. Antiangiogenic arming of an oncolytic vaccinia virus enhances antitumor efficacy in renal cell cancer models. J Virol. 2010;84(2):856-866.

68. Olofsson B, Korpelainen E, Pepper MS, et al. Vascular endothelial growth factor B (VEGF-B) binds to VEGF receptor-1 and regulates plasminogen activator activity in endothelial cells. Proc Natl Acad Sci US A. 1998;95(20):11709-11714.

69. Patil SS, Gentschev I, Adelfinger M, et al. Virotherapy of canine tumors with oncolytic vaccinia virus GLV-1h109 expressing an anti-VEGF single-chain antibody. PLoS One. 2012;7(10):e47472.

70. Gupta P, Su ZZ, Lebedeva IV, et al. mda-7/IL-24: multifunctional cancer-specific apoptosis-inducing cytokine. Pharmacol Ther. 2006;111(3):596-628.

71. Lebedeva IV, Emdad L, Su ZZ, et al. mda-7/IL-24, novel anticancer cytokine: focus on bystander antitumor, radiosensitization and antiangiogenic properties and overview of the phase I clinical experience (Review). Int J Oncol. 2007;31(5):985-1007.

72. Fan JK, Wei N, Ding M, et al. Targeting Gene-ViroTherapy for prostate cancer by DD3-driven oncolytic virus-harboring interleukin-24 gene. Int $J$ Cancer. 2010;127(3):707-717.

73. Xiao LL, Wu YM, Qian J, et al. The antitumor efficacy of IL-24 mediated by E1A and E1B triple regulated oncolytic adenovirus. Cancer Biol Ther. 2010;10(3):242-250.

74. Chai L, Liu S, Mao Q, et al. A novel conditionally replicating adenoviral vector with dual expression of IL-24 and arresten inserted in E1 and the region between $\mathrm{E} 4$ and fiber for improved melanoma therapy. Cancer Gene Ther. 2012;19(4):247-254.

75. Xie K. Interleukin-8 and human cancer biology. Cytokine Growth Factor Rev. 2001;12(4):375-391.

76. Yoo JY, Kim JH, Kim J, et al. Short hairpin RNA-expressing oncolytic adenovirus-mediated inhibition of IL-8: effects on antiangiogenesis and tumor growth inhibition. Gene Ther. 2008;15(9):635-651.

77. Cao R, Farnebo J, Kurimoto M, Cao Y. Interleukin-18 acts as an angiogenesis and tumor suppressor. FASEB J. 1999;13(15): 2195-2202.

78. Brunda MJ, Luistro L, Warrier RR, et al. Antitumor and antimetastatic activity of interleukin 12 against murine tumors. $J$ Exp Med. 1993;178(4):1223-1230.
79. Maione TE, Gray GS, Petro J, et al. Inhibition of angiogenesis by recombinant human platelet factor-4 and related peptides. Science. 1990;247(4938):77-79.

80. Liu TC, Zhang T, Fukuhara H, et al. Oncolytic HSV armed with platelet factor 4, an antiangiogenic agent, shows enhanced efficacy. Mol Ther. 2006;14(6):789-797.

81. Varghese S, Rabkin SD, Liu R, Nielsen PG, Ipe T, Martuza RL. Enhanced therapeutic efficacy of IL-12, but not GM-CSF, expressing oncolytic herpes simplex virus for transgenic mouse derived prostate cancers. Cancer Gene Ther. 2006;13(3):253-265.

82. Wong RJ, Chan MK, Yu Z, et al. Angiogenesis inhibition by an oncolytic herpes virus expressing interleukin 12. Clin Cancer Res. 2004;10(13):4509-4516.

83. Meadows KN, Bryant P, Vincent PA, Pumiglia KM. Activated Ras induces a proangiogenic phenotype in primary endothelial cells Oncogene. 2004;23(1):192-200.

84. Lamfers ML, Gianni D, Tung CH, et al. Tissue inhibitor of metalloproteinase-3 expression from an oncolytic adenovirus inhibits matrix metalloproteinase activity in vivo without affecting antitumor efficacy in malignant glioma. Cancer Res. 2005;65(20):9398-9405.

85. Folkman J. Endogenous angiogenesis inhibitors. APMIS. 2004;112(7-8): 496-507.

86. Li G, Sham J, Yang J, et al. Potent antitumor efficacy of an E1B 55 kDadeficient adenovirus carrying murine endostatin in hepatocellular carcinoma. Int J Cancer. 2005;113(4):640-648.

87. Li GC, Yang JM, Nie MM, et al. Potent antitumoral effects of a novel gene-viral therapeutic system CNHK300-mEndostatin in hepatocellular carcinoma. Chin Med J (Engl). 2005;118(3):179-185.

88. Mullen JT, Donahue JM, Chandrasekhar S, et al. Oncolysis by viral replication and inhibition of angiogenesis by a replication-conditional herpes simplex virus that expresses mouse endostatin. Cancer. 2004;101(4):869-877.

89. Su C, Na M, Chen J, et al. Gene-viral cancer therapy using dual-regulated oncolytic adenovirus with antiangiogenesis gene for increased efficacy. Mol Cancer Res. 2008;6(4):568-575.

90. Zhang Q, Nie M, Sham J, et al. Effective gene-viral therapy for telomerase-positive cancers by selective replicative-competent adenovirus combining with endostatin gene. Cancer Res. 2004;64(15): 5390-5397.

91. Pan JG, Zhou X, Zeng GW, Han RF. Potent antitumour activity of the combination of HSV-TK and endostatin armed oncolytic adenoassociated virus for bladder cancer in vitro and in vivo. J Surg Oncol. 2012;105(3):249-257.

92. Goodwin JM, Schmitt AD, McGinn CM, et al. Angiogenesis inhibition using an oncolytic herpes simplex virus expressing endostatin in a murine lung cancer model. Cancer Invest. 2012;30(3):243-250.

93. Yang L, Wang L, Su XQ, et al. Suppression of ovarian cancer growth via systemic administration with liposome-encapsulated adenovirusencoding endostatin. Cancer Gene Ther. 2010;17(1):49-57.

94. Zhang W, Fulci G, Buhrman JS, et al. Bevacizumab with angiostatinarmed oHSV increases antiangiogenesis and decreases bevacizumabinduced invasion in U87 glioma. Mol Ther. 2012;20(1):37-45.

95. Scappaticci FA, Contreras A, Smith R, et al. Statin-AE: a novel angiostatin-endostatin fusion protein with enhanced antiangiogenic and antitumor activity. Angiogenesis. 2001;4(4):263-268.

96. Li X, Liu YH, Lee SJ, Gardner TA, Jeng MH, Kao C. Prostate-restricted replicative adenovirus expressing human endostatin-angiostatin fusion gene exhibiting dramatic antitumor efficacy. Clin Cancer Res. 2008;14(1):291-299.

97. Yang CT, Lin YC, Lin CL, et al. Oncolytic herpesvirus with secretable angiostatic proteins in the treatment of human lung cancer cells. Anticancer Res. 2005;25(3B):2049-2054.

98. Tysome JR, Briat A, Alusi G, et al. Lister strain of vaccinia virus armed with endostatin-angiostatin fusion gene as a novel therapeutic agent for human pancreatic cancer. Gene Ther. 2009;16(10): $1223-1233$. 
99. Tysome JR, Wang P, Alusi G, et al. Lister vaccine strain of vaccinia virus armed with the endostatin-angiostatin fusion gene: an oncolytic virus superior to d11520 (ONYX-015) for human head and neck cancer. Hum Gene Ther. 2011;22(9):1101-1108.

100. Cao Y, Chen A, An SS, Ji RW, Davidson D, Llinás M. Kringle 5 of plasminogen is a novel inhibitor of endothelial cell growth. $J$ Biol Chem. 1997;272(36):22924-22928.

101. Fan JK, Xiao T, Gu JF, et al. Increased suppression of oncolytic adenovirus carrying mutant $\mathrm{k} 5$ on colorectal tumor. Biochem Biophys Res Commun. 2008;374(2):198-203.

102. He XP, Su CQ, Wang XH, et al. E1B-55kD-deleted oncolytic adenovirus armed with canstatin gene yields an enhanced anti-tumor efficacy on pancreatic cancer. Cancer Lett. 2009;285(1):89-98.
103. Hardcastle J, Kurozumi K, Dmitrieva N, et al. Enhanced antitumor efficacy of vasculostatin (Vstat120) expressing oncolytic HSV-1. Mol Ther. 2010;18(2):285-294.

104. Liu TC, Zhang T, Fukuhara H, et al. Dominant-negative fibroblast growth factor receptor expression enhances antitumoral potency of oncolytic herpes simplex virus in neural tumors. Clin Cancer Res. 2006;12(22):6791-6799.

105. Jain RK, Finn AV, Kolodgie FD, Gold HK, Virmani R. Antiangiogenic therapy for normalization of atherosclerotic plaque vasculature: a potential strategy for plaque stabilization. Nat Clin Pract Cardiovasc Med. 2007;4(9):491-502.

\section{Publish your work in this journal}

OncoTargets and Therapy is an international, peer-reviewed, open access journal focusing on the pathological basis of all cancers, potential targets for therapy and treatment protocols employed to improve the management of cancer patients. The journal also focuses on the impact of management programs and new therapeutic agents and protocols on

\section{Dovepress}

patient perspectives such as quality of life, adherence and satisfaction. The manuscript management system is completely online and includes a very quick and fair peer-review system, which is all easy to use. Visit http://www.dovepress.com/testimonials.php to read real quotes from published authors. 